\title{
Limiting foetal doses during a four-vessel angiogram and endovascular stent-assisted berry aneurysm repair: A case report
}

\begin{tabular}{|c|c|}
\hline \multicolumn{2}{|c|}{$\begin{array}{l}\text { Authors: } \\
\text { Demaré Potgieter } \\
\text { William I.D. Rae }^{1} \text { (1) } \\
\text { Coert S. de Vries }\end{array}$} \\
\hline \multicolumn{2}{|c|}{$\begin{array}{l}\text { Affiliations: } \\
\text { }{ }^{1} \text { Department of Medical } \\
\text { Physics (G68), University of } \\
\text { the Free State, South Africa }\end{array}$} \\
\hline \multicolumn{2}{|c|}{$\begin{array}{l}{ }^{2} \text { Department of Clinical } \\
\text { Imaging Sciences (G61), } \\
\text { University of the Free State, } \\
\text { South Africa }\end{array}$} \\
\hline \multicolumn{2}{|c|}{$\begin{array}{l}\text { Corresponding auth } \\
\text { William Rae, } \\
\text { raewid@ufs.ac.za }\end{array}$} \\
\hline \multicolumn{2}{|c|}{$\begin{array}{l}\text { Received: } 13 \text { Feb. } 2017 \\
\text { Accepted: } 30 \text { Apr. } 2017 \\
\text { Published: } 30 \text { June } 2017\end{array}$} \\
\hline \multicolumn{2}{|c|}{$\begin{array}{l}\text { How to cite this article: } \\
\text { Potgieter D, Rae WID, De } \\
\text { Vries CS. Limiting foetal } \\
\text { doses during a four-vessel } \\
\text { angiogram and endovascular } \\
\text { stent-assisted berry } \\
\text { aneurysm repair: A case } \\
\text { report. S Afr J Rad. 2017; } \\
\text { 21(1), a1188. https://doi. } \\
\text { org/10.4102/sajr.v21i1.1188 }\end{array}$} \\
\hline \multicolumn{2}{|c|}{$\begin{array}{l}\text { Copyright: } \\
\text { ๔ 2017. The Authors } \\
\text { Licensee: AOSIS. This } \\
\text { is licensed under the } \\
\text { Creative Commons } \\
\text { Attribution License. }\end{array}$} \\
\hline \multicolumn{2}{|l|}{ Read online: } \\
\hline 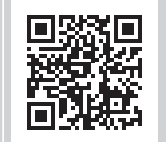 & $\begin{array}{l}\text { Scan this QR } \\
\text { code with your } \\
\text { smart phone or } \\
\text { mobile device } \\
\text { to read online. }\end{array}$ \\
\hline
\end{tabular}

A 36-year-old female patient, 20 weeks pregnant, was diagnosed with a left internal carotid artery aneurysm. Fluoroscopically guided repair was justified. A four-vessel cerebral angiogram was performed, and a left paraclinoid aneurysm was demonstrated. The patient subsequently underwent endovascular stent-assisted berry aneurysm repair. As the patient was pregnant, the procedure was preceded by consideration of the required radiation protection. The foetal dose was estimated as negligible. Active management of foetal exposures may improve radiation protection during pregnancy.

\section{Introduction}

Endovascular treatment of a pregnant patient constitutes additional radiation risk to the foetus, owing to the increased radiobiological sensitivity of foetal cells. ${ }^{1}$ Risk reduction is important to minimise stochastic effects.

\section{Case report}

A 36-year-old female patient, who was 20 weeks pregnant, was referred to the Universitas Academic Hospital in Bloemfontein, with a suspected left internal carotid artery (ICA) aneurysm. She presented with a chronic headache and dysphasia. Magnetic resonance imaging (MRI) was performed, showing a left ICA aneurysm and infarction, which was possibly related to emboli from the aneurysm. The patient was counselled regarding treatment options. The possible adverse effects of the radiation on her baby, and their mitigation, were explained. A four-vessel cerebral angiogram was performed on the patient, and a left paraclinoid aneurysm, which appeared to be superiorly projecting, was demonstrated (Figure 1).

It was recommended that the patient undergo an endovascular stent-assisted repair, as open surgery would pose a high risk to the unborn. The multi-lobulated dome made rupture likely and allowing the pregnancy to continue without the treatment of the aneurysm could have serious consequences.

Before the procedure, a medical physicist was consulted to determine the radiation protection measures required to protect the foetus. Accordingly, a RADOS RAD-60 personal alarm dosimeter with a measurement range of $1 \mu \mathrm{Sv}$ to $9.99 \mathrm{~Sv}$ was placed on the patient's abdomen with the limit set to $1 \mathrm{mSv}$ (annual dose limit for a member of the public). A lead apron, with $0.25 \mathrm{~mm}$ lead thickness equivalence, was placed under the patient's abdomen, and an additional lead apron, with $0.35 \mathrm{~mm}$ lead thickness equivalence, was placed over her abdomen and over the alarm dosimeter, thus shielding the foetus. This was used as a precautionary measure to ensure that the dose, from sources external to the patient, to the foetus, is negligible. Internal scatter cannot be modified, and as the radiation is to the head in this case, internal scatter is assumed to be minimal at the fluoroscopic energies used.

Ultrasound-guided puncture was made in the right femoral artery, and a $6 \mathrm{~F}$ sheath set was placed. Via exchange, a 6-F-guiding catheter was placed in the left ICA after which a micro-catheter was placed passing the aneurysm to the middle of the cerebral artery. A second micro-catheter was then placed in the aneurysm. Via the first micro-catheter, an endovascular remodelling device of size $4 \mathrm{~mm} \times 20 \mathrm{~mm}$ was placed covering the aneurysm neck. Via the second micro-catheter, the aneurysm was then successfully embolised with seven detachable coils. The control angiogram demonstrated no aneurysmal flow, and all vessels were patent (Figure 2). The stent was detached, and the catheters and guide catheter were removed. The sheath was left in place and removed when clotting was normalised. 

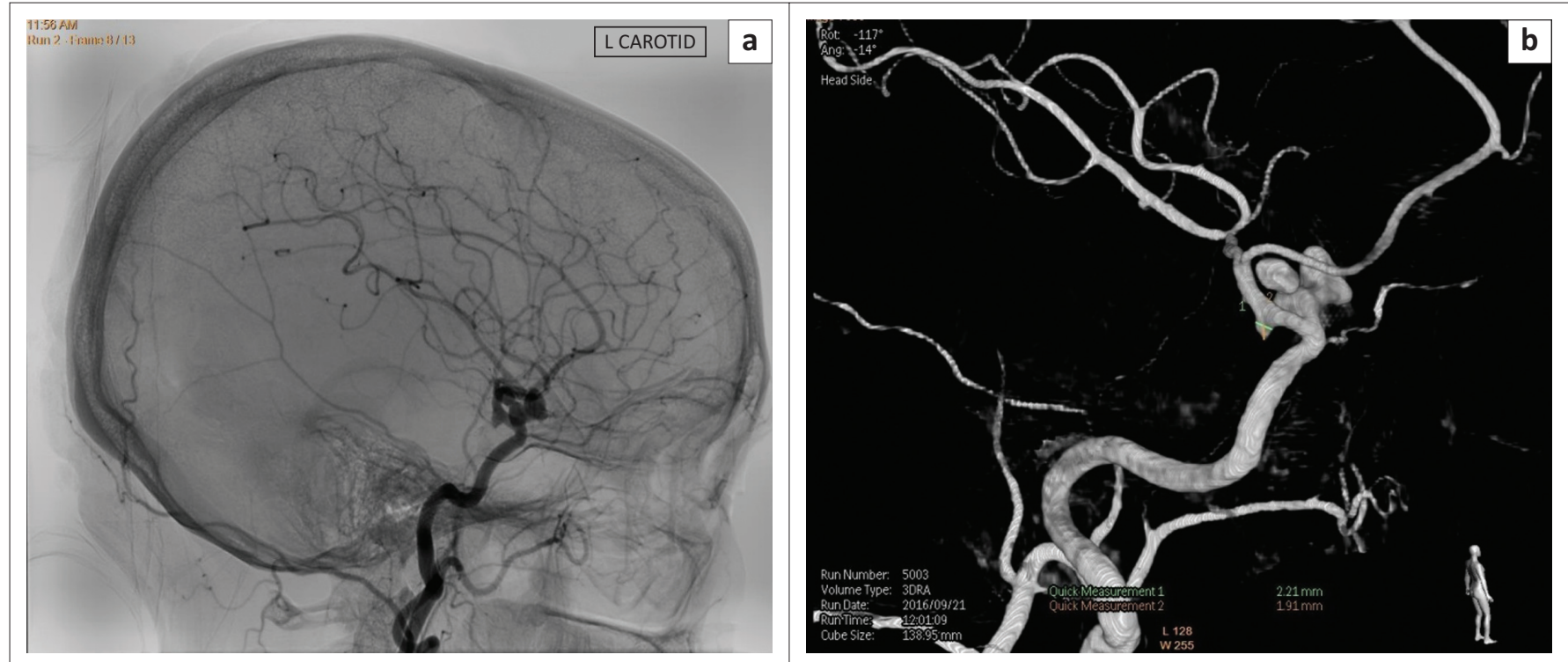

FIGURE 1: (a) Fluoroscopic image of the complex aneurysm protruding superiorly from the left carotid artery and (b) three-dimensional rendering of the aneurysm.

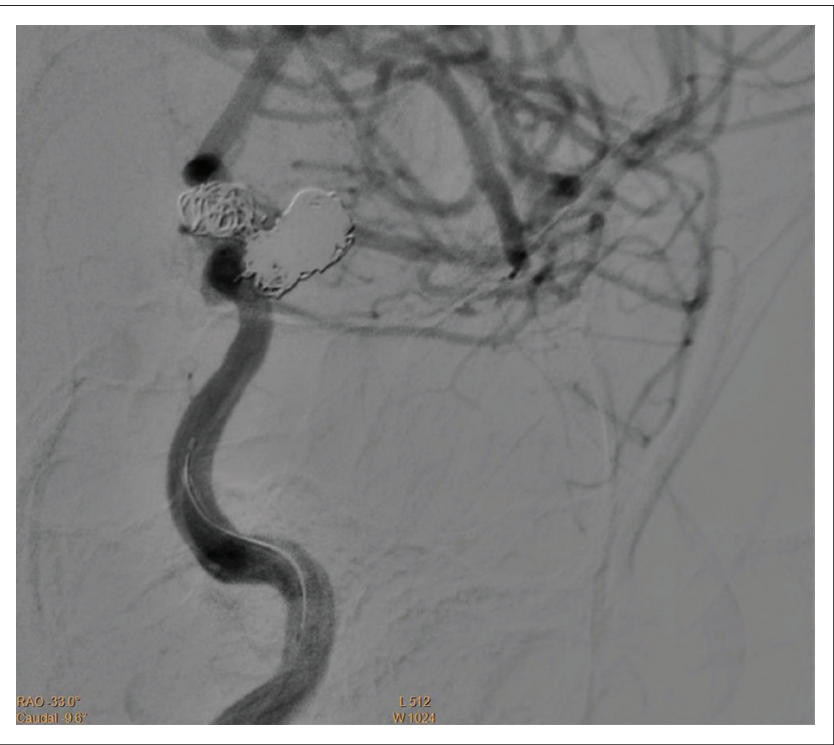

FIGURE 2: The repaired aneurysm showing no aneurysmal flow and all the adjoining vessels patent.

TABLE 1: Parameters used during procedures and recorded DAP meter readings.

\begin{tabular}{lllllll}
\hline Procedure & $\begin{array}{l}\text { SID } \\
(\mathbf{c m})\end{array}$ & $\begin{array}{l}\text { Field size } \\
\left(\mathbf{c m}^{2}\right)\end{array}$ & $\mathbf{k V}$ & $\begin{array}{l}\text { Time } \\
(\mathbf{m i n})\end{array}$ & Filter & $\begin{array}{l}\text { DAP } \\
\left(\mathbf{m G y} . \mathbf{c m}^{2}\right)\end{array}$ \\
\hline $\begin{array}{l}\text { Four-vessel } \\
\text { angiogram }\end{array}$ & 111 & $31 \times 31$ & 80 & $8: 13$ & $\begin{array}{l}0.1 \mathrm{mmAl}+ \\
0.1 \mathrm{mmCu}\end{array}$ & 24077 \\
$\begin{array}{l}\text { Endovascular } \\
\text { stent-assisted } \\
\text { aneurysm repair }\end{array}$ & 120 & $15 \times 15$ & 80 & $43: 36$ & $\begin{array}{l}0.1 \mathrm{mmAl}+ \\
0.1 \mathrm{mmCu}\end{array}$ & 50999 \\
\hline
\end{tabular}

DAP, dose area product; SID, source-isocenter distance.

Foetal radiation exposure was limited by using fluoro roadmaps, minimal angiogram exposures, pulsed fluoroscopy and shielding the abdomen. The alarm dosimeter reading after the completion of the procedure was $1 \mu \mathrm{Sv}$. The exposure parameters and dose area product (DAP) values were recorded (Table 1).

DAP meters are widely used in interventional X-ray units, however, the radiation hazard cannot readily be obtained from the DAP value. Kisielewicz et al. formulated a relationship to estimate the patient entrance surface dose (ESD) from the DAP values. ${ }^{2}$ This relationship, however, can only be used as a guideline because the parameters used in this case and that used by Kisielewicz et al. differ to some extent. Using this relationship, the patient ESD, after the four-vessel angiogram, was $100.82 \mathrm{mGy}$ and for the endovascular stent-assisted aneurysm repair was $826.45 \mathrm{mGy}$, which was found to be $23.67 \%$ of the diagnostic reference level (DRL) used in our Department.

The ESD values calculated the approximate entrance dose. This was predominantly to the patient's head. To calculate the foetal dose, the uterine dose was calculated using PCXMC ${ }^{\circledR}$ software for calculating organ and effective doses in radiography and fluoroscopy examinations. This Monte Carlo-based method was developed by STUK (The Radiation and Nuclear Safety Authority in Finland). ${ }^{3}$ The software assumes a patient height of $178.6 \mathrm{~cm}$, weight of $73.20 \mathrm{~kg}$ and age of 30 years. The software calculated the total uterine dose, which was used as a surrogate for dose to the foetus as being at the background level.

\section{Ethical considerations}

The study protocol was approved by the Health Sciences Research Ethics Committee, University of the Free State [HSREC 200/2016].

\section{Discussion}

The International Commission on Radiological Protection (ICRP) Report 84 defines several situations in which radiation use is appropriate. ${ }^{4}$ Any examination or therapy involving radiation exposure of a pregnant patient should be justified and optimised, however negligible the radiation exposure might be..$^{5}$ In this case, the aneurysm appeared to be unruptured, but because of the multi-lobulated dome, rupture was considered likely. Allowing the pregnancy to continue 
without aneurysm repair could have had serious shortterm consequences - thus, the procedure was justified. For optimisation, clinical purpose should be achieved with a minimal radiation dose delivered to the foetus. ${ }^{4}$ Here, the dose was reduced by using appropriate radiation protection, including fluoro roadmaps, minimal angiogram exposures, pulsed fluoroscopy and shielding. The dosimeter confirmed that the doses measured were indeed minimal.

According to the ICRP, prenatal doses from most diagnostic procedures conducted properly will not cause any adverse effects to the foetus. Dose-dependent exposure risk depends on gestational age, being maximal during organogenesis and the early foetal period. ${ }^{1}$ The current acceptable cumulative dose of ionising radiation to the foetus is $50 \mathrm{mGy},{ }^{4}$ but current data suggest that there is no increase in the incidence of gross congenital malformation in humans during pregnancy at doses less than $200 \mathrm{mGy}^{6}$ In this case, the foetus received doses well below these threshold values.

\section{Conclusion}

This case report demonstrates that radiation protection measures can be successfully employed for pregnant patients requiring head and neck interventional procedures, and it was used to educate and reassure the interventional team. Adequate shielding of the abdomen and good technique gave the team confidence that there would be a negligible dose to the foetus, well below the threshold values for increased risk.

\section{Acknowledgements}

The authors thank the staff of the Clinical Imaging Sciences Department, School of Medicine, University of the Free State, for assistance in obtaining information regarding the procedure. They also thank Ms. T. Mulder, medical editor, School of Medicine, University of the Free State, for technical and editorial preparation of the manuscript.

\section{Competing interests}

The authors declare that they have no conflict of interest.

\section{Authors' contributions}

D.P. was the main researcher. She collected, processed and analysed the data and was the primary author of this document. W.I.D.R was the main supervisor and was involved in the writing of the manuscript as well interpreting the results. C.S.d.V. was involved in the conception as well as in the writing of the manuscript.

\section{References}

1. Hojreh A, Prosch H, Karanikas G, Homolka P, Trattnig S. Protection of the unborn child in diagnostic and interventional radiological procedures. Radiologe. 2015;55(8):663-672. (Article in German). https://doi.org/10.1007/s00117-0152816-x

2. Kisielewicz K, Truszkiewicz A, Wach S, Wasilewska-Radwańska M. Evaluation of dose area product vs. patient dose in diagnostic X-ray units. Phys Med. 2011;27(2):117-120. https://doi.org/10.1016/j.ejmp.2010.07.001

3. Tapiovaara M, Siiskonen T. PCXMC 2.0. User's Guide. STUK-TR 7. c2008 [cited 2017 Feb 8]. Available from: https://www.stuk.fi/documents/12547/474783/stuk-tr7. pdf/6f42383b-be6d-468a-9a00-a49ca8c9ef31

4. International Commission on Radiological Protection (ICRP). Pregnancy and medical radiation. ICRP Publication 84. Ann ICRP. 30(1). C2000 [cited 2017 Feb 8]. Available from: http://www.icrp.org/publication.asp?id=ICRP\%20Publication\% 2084

5. Gomes M, Matias A, Macedo F. Risks to the fetus from diagnostic imaging during pregnancy: Review and proposal of a clinical protocol. Pediatr Radiol. 2015;45(13):1916-1929. https://doi.org/10.1007/s00247-015-3403-z

6. Austin LM, Frush DP. Compendium of national guidelines for imaging the pregnant patient. AJR Am J Roentgenol. 2011;197(4):W737-W746. https://doi.org/ 10.2214/AJR.10.6351 